\title{
Right to be Wrong: If Brain is Guilty, are We Responsible?
}

\author{
Dragan Pavlovic*
}

Department of Anaesthesiology and Intensive Care Medicine, Ernst Moritz Arndt University, Greifswald, Germany

\begin{abstract}
There are experts in ethics who apparently maintain that if genetic factors result in criminal behaviour, then the perpetrator is responsible for his acts. As David Papineau puts it in his review: If criminal tendencies are foisted on you by your genes, you are still responsible for succumbing to these desires. If you are capable of deliberation, it's still up to you whether or not you give in to those tendencies (our rephrasing). This claim needs important amendment. You may be morally responsible, we maintain, only if your genes can not influence your capacity of deliberation, but since they could and probably often will, the original claim is not false but incomplete. In addition, the capacity for deliberation may be far too insufficient to enable us to make infallible moral judgements. Someone may be capable of moral deliberation - but this would not guarantee an acceptable result. To be able to behave in morally justified ways we need, for example, not only adequate knowledge, but also a rich socially modelled background allowing for the development of satisfactory empathy - something that may not always properly apply because of disease or other extreme circumstances. These may, in turn, be a result of cultural specificity, difficult living conditions, emotional states, extreme fatigue or the stress of war. These are closely related to another quite early identified question: which is more important, an individual as a pure social subject, or as an independent human entity. If we could agree that such dualistic morality may be simply a compromise between individually and socially determined morality, we might secure more solid grounds for our actions.
\end{abstract}

Key Words: Moral responsibility, genes, deliberation, desires, tendencies.

\section{BACKGROUND}

Moral qualification of our behaviour and of the results of our acting or not acting imposes moral responsibility. Classically, we may be held morally responsible and accountable in as far as we knew (or would be expected to have known) what we were doing, under the conditions that we could have done otherwise (the principle of alternate possibilities PAP) [1]. Sometimes neither of these two apply and we, although responsible, could not be held morally responsible i.e. accountable and would not provoke reactive attitudes and practices of either praise or blame. As we will see, this is not always as evident as it sometimes look like to be.

There are experts in ethics who apparently maintain that if genetic factors result in criminal behaviour, then "you" are responsible for your acts. This seems quite a strange solution to the responsibility problem. Nevertheless, David Papineau states the following in his recent review [2] (our rephrasing):

If criminal tendencies are foisted on you by your genes, you are still responsible for succumbing to these desires. If you are capable of deliberation, it's still up to you whether or not you give in to those tendencies.

We entirely agree with Professor Papineau, but would object to the statement that it is incomplete in a quite limited, but important sense. The desires and tendencies, and the capabilities of deliberation probably can not be separated. The importance of the coincidence of the genetically determined

*Address correspondence to this author at the Research Director, Klinik und Poliklinik für Anästhesiologie und Intensivmedizin, Ernst-Moritz-Arndt Universität, Friedrich-Loeffler-Strasse 23b, 17487 Greifswald, Germany; Tel: (49) 38348658 48; Fax: (49) 38348658 02;

E-mail:pavlovic@uni-greifswald.de tendencies and limitations of free deliberation may be far reaching and we will, to some extent, explore this below. Beforehand, let us look briefly at the origins of the debate.

The recently reviewed book [3] and the review itself [2] raise the above mentioned problem of "moral responsibility" and while the reviewer maintains that the authors respond in the way given in the citation, there is nothing so explicit in the cited book that would support that claim. All of the cited authors [4-8] explicitly agree that our behaviour may be and probably is influenced by the causes beyond our control and that this may have serious repercussions on our understanding of moral responsibility [4]. The authors also agree that we are still far from explaining human behaviour and corresponding legal changes are not to be expected in the immediate future [5, 7]. [3].

To put it simply, we believe that the following was said

p. The modern neuroscience cannot say whether "criminal tendencies are foisted on you by your genes or not".

q. Therefore it must be, at present, concluded that "you are responsible for succumbing to criminal desires".

All of the authors also imply - and Bateson declares: "My own view is that we should assume intentionality, and hence responsibility, until we have very good reason to think otherwise." [5]. Implying that when we will know that "criminal tendencies are foisted on you by your genes," the moral responsibility would have to be re-examined. Some tension between this affirmation and the statements implying responsibility in spite of our genes [2] is obvious.

One question that should be answered is when holding them "morally responsible" would be the right thing to say. 
An easier case would be when we know that some criminal tendencies may be explained by environmental or even genetic factors or be caused by some disease leading to, for example, an abnormal level of some excitatory amino acid in their brain. More difficult would be to establish whether are we justified in believing that people are "morally responsible" for their acts when quite vague external causal agent is identified, for example: if obvious social modelling is involved, or if is identified? Finally, an additional question to be answered is whether, in principle, we should hold such people morally responsible when a causal agent is not identified, but available knowledge in neurobiology and psychology suggests that it may be or must be present.

\section{ARGUMENT}

Two examples are needed to illustrate a dilemma: the first should illustrate the situation when a causal factor is temporarily present; the second situation when the causal factor is present from birth. Imagine, I started every evening to put a substance in your drink that will make you (temporarily) a criminal, who would kill a policeman on sight. You kill one, are put in prison, and the effect of the drug slowly disappears... Do you feel responsible? The family of the killed policeman would say that you did it, the judge would say it also, maybe you would admit it, but would you be responsible? We think you would say: no, that was not "ME". I am accountable for that act, but certainly not morally responsible.

Or imagine, just one tiny section of your genes do not quite fit together. Otherwise you read Shakespeare, love your wife and children, work well and are quite okay. But when you see a red sky in the evening your genes cause you to want to kill someone. And you do it a couple of times, are imprisoned and sentenced to the electric chair. Then you hear of a doctor, who examines genetic codes and can localize the bad gene. You get him to treat you, the cure is simple, and you are cured. But you are still condemned to death. Are you still guilty? Were you ever guilty and were you morally responsible? We suggest that the use of the expression "responsibility", "moral responsibility" and "accountability" need to be redefined.

The essence of the problem could be state as follows: If both, the capacity to resist criminal tendencies and the shaping of our intentions are determined by our genes, then we would have a hard time in deciding whether there is moral responsibility or not. A mentally ill person may display criminal behaviour and have some well organised criminal intentions, but if the causal agent is a gene or a brain defect, and she/he could not have acted otherwise [1], why would that person be considered morally responsible? There are exceptions of course, like if one would have pleasure in doing something immoral, which in any case, could not have been avoided.

Indeed, we had a brief correspondence with Professor Papineau and it appears that our views do not differ at all and that the problem is not in what was written in the review, but rather what was not. As a result, we fear that the readers could misinterpret an essential point. The important question is: how do we know that someone is capable of deliberation? This could not be measured. Therefore, our response would be that we have to have some a priori position in respect to organic or functional abnormalities of the human brain and capability to deliberate which would help us deciding about moral responsibility.

\section{CAPABILITY TO DELIBERATE}

How can we explain behaviour (when behaviour is only aspect of his mental activity accessible) of an actor who, let us suppose, has both, bad genes and bad tendencies, but apparently never succumbs to them - will this be proof that she/he is capable of deliberation? Or on the contrary, if someone has bad genes and bad tendencies, and she/he appears to succumb to them - how will we know whether she/he was "in fact" capable of deliberation? Her/his capability to deliberate may have been limited in that particular respect - we suspect that paedophiliacs, for example, could be that kind of people. As a result, we think that we are almost always obliged to judge an actor who succumbs to such immoral drives, to certain extent, as incapable of deliberation. Indeed, in making moral judgements, we are little concerned with what produced the act but almost exclusively with the nature of the act itself. As a result we condemn paedophiliacs but not obsessive-compulsive patients. A person, whose general capacity for deliberation is beyond doubt, may sometimes suffer from compulsive-obsessive drives which, if resulting in acts forbidden by law, would certainly be held responsible. Indeed we know how hard it is for an otherwise intelligent and normal person - capable of deliberation in practically any respect - to rid him/herself, for example, of compulsively washing their hands. We are prepared to conclude that in this particular respect, such a person cannot help succumbing to her/his tendencies. Such a person is "a patient"; could we yet, for another with criminal drives claim not to be a "patient"?

If we believe that merely by declaring an actor to be morally responsible would produce learning effects and improve her/his further behaviour, we may say that the actor was capable of deliberation and proceed with blaming and punishing. Therefore, our solution is based on the presumption that we cannot develop a genuine blame for that person, but we may do so only if either the act of blaming would be expected to have some general social effects (resulting in broad social re-education or promotion of moral values), and/or will have re-educative effects on the actor. These effects will be certainly very limited in the cases, where classically we were deciding that diminished responsibility applies. If we think that the actor would not "profit" (learn) from our holding her/him responsible, we will have to employ "diminished responsibility" reasoning. We may have deontological reasons for condemning the action, but this should not interfere with our granting some degree of diminished responsibility to the actor. Blaming (morally) a person with the intellectual level of idiocy, of murder for killing a child, is absurd and may be justified only as a demonstration of our moral stance toward such an act, with possible social effects on a larger scale. We also sometimes tend to blame inanimate objects, but in fact what we do is that we are reinforcing some of our own moral concerns. These motives may justify blaming some people who, because mentally disturbed, could not have acted otherwise [1], although the blame most often would not be "touching" the real actor at all and would serve some of the other merely social purposes. 
Nevertheless, these moral brainteasers are closely related to another moral problem: the question of whether an individual should be treated as a purely social subject or as an independent human (and humane) entity. The latter is however an aspect that is almost missing in the above mentioned book review (the issue is just briefly mentioned by [7]) so that the treatment of a human being as solely a social subject predominates. The strange "solution" to the responsibility problem, which has been put forward in the mentioned book review [2] is, we suspect, a result of a tendency, imported from the natural sciences, to neglect the individual for the sake of the "whole". Maybe this is a "side effect" of indeterminism. We will then first examine some aspects of causal relationships and then turn briefly to the dichotomy of individual vs. the whole.

\section{DESIRES AND TENDENCIES}

The doctrine that we want to challenge implies that you could be morally responsible for your actions even if such actions are, or just could be, determined by your genes which you cannot control - thereby violating PAP [1]. In addition, the unpleasant consequence of the above mentioned position may be to a priori justify the absence of a potential awareness of what can be termed "human essence" or "human value" - as some would put it [9] - of the person displaying criminal behaviour, and to forget that a human being is behind these criminal acts, no matter how brutal these acts may have been.

It is commonly accepted that human tendencies spring, between number of other things, from human concerns that are generated by the relationships establishing roles and obligations and what is desired is determined by our particular concerns [10]. Some desires may not be approved by society at large and would be considered as immoral or "criminal" desires. People, who we consider to be normal and have a "moral personality" [11] may often - or possibly always have some secret immoral desires and tendencies. They manage, nevertheless, to limit their concerns to those that are socially acceptable, and thereby model their desires and behaviour accordingly. They will pursue those tendencies that are morally approved and behave accordingly. It is clear that not all people are capable of doing so. Sometimes, socially undesirable concerns, desires, tendencies and even actions, will surface. Some would display anti-social behaviour as a result of influences of complex social factors, or display a deficient cognitive status: as a result the person may have a dangerous misconception of how the world functions and would consider appropriate his or her anti-social behaviour. This may produce variable final outcomes. Some people that have experienced moral failure can be brought back into society; others cannot and are put in isolation. If their crimes are excessive, they are imprisoned or (in some societies) even executed in order to maintain and reinforce moral rules or to protect society by temporarily or permanently depriving them of social contacts.

\section{THE INDIVIDUAL OR THE WHOLE}

The dichotomy of individual vs. the whole is mirrored in the confrontation of morality of or for society and morality of or for an individual. These two are partially incompatible. The roots of the problem are quite ancient. They were identified probably before Aristotle and have been extensively discussed since. Aristotle believed that the whole is more important that its parts and that the interests of a society are superior to those of an individual $[12,13]$. Today we often hear that the individual is at the centre of our moral concerns. The first will impose the rule that the laws of society must be obeyed and all members should accept their punishment if they breach the law, even if they themselves believed that they were not responsible for having committed a contravention. The flagrant example is an unlucky tourists who is visiting a foreign country and who commits a "crime" in ignorance of the laws of that country. This is in opposition to the case of individual morality, which holds that the person, who does not know what he/she is doing, is not responsible for the given anti-social acts. The tension is obvious. If we would then accept what Papineau says (cited above), we would in fact accept favouring morality for society at large and dismiss assumptions of individual morality. On the other hand, acceptance of the primacy of individual morality would obviously render someone to be not responsible, who does not know either that what she/he is doing is wrong, or that the consequences of that act are immoral.

\section{SOCRATIC PARADOX}

Why would I deliberately do something wrong? Certainly, one may be an irrational person, mentally disturbed and acting against ones own interests. But that person could not be said to be acting voluntarily and thereby would not be responsible. Maybe I would be acting in such a way because I thought that this was in fact a correct action. For example, I could hold that my immediate personal interests (pleasure for example) are primordial and believe that the world functions exactly like this (most criminals think this way). This in fact, would mean that I act wrongly, while still believing to be behaving correctly. But I would still be acting without knowing what I am doing and thereby could not be held accountable for my acts in spite of the fact that I may be causally responsible for these actions ("Socratic paradox", for description see references $[14,15])$. Certainly, a number of wrong actions are committed out of negligence that would justify reactive attitudes and related practices.

For all these situations it would appear that adequate practices (isolation, education, socialisation) should be accompanied by all measures assuring full respect for the subject's human nature [9]. And, on the contrary, it appears that an exclusive holistic approach may turn out to be quite demonic. Obviously, those acting for the sake of "highest" values would, most likely, rationally ignore the unique value of human life - and would be ready to punish someone because she/he happened (probably!) to have bad genes.

\section{CONCLUSIONS}

We maintained above that you may be considered morally responsible only if your genes cannot influence your capacity of deliberation, but since they could, your degree of responsibility must be limited. In addition, the capacity for deliberation may be far too insufficient to enable us to make infallible moral judgements. On the other hand, if we accept that social morality is above individual morality, we would have to accept punishing a person who is, in respect to individual morality, not morally responsible and this would mean that we will be accepting injustice. Unfortunately, the world, seems to be made of opposites that cannot always be 
reconciled. If we would agree that such dualistic morality could at best be a compromise between individually and socially determined morality, we might secure a more solid ground for our actions. Probably we would not substantially alter our treatment of the majority of people who contravene society's rules. However, institutions treating those, who committed acts against society, would be encouraged to distinguish between moral responsibility and accountability. This might result in the reshaping of the institutions to take on a more humane role. The second benefit from such a dualistic approach to the problem of responsibility, could be that we finally see why retribution of any kind is absurd and why capital punishment is grossly unacceptable.

\section{REFERENCES}

[1] Frankfurt GH. Alternate possibilities and moral responsibility. J Phil 1969; 66 (23): 829-39.

[2] Papineau D. Looking ahead to future brain studies. Nature 2005; 433: 803.

[3] Rees D, Rose S, Eds. The New Brain Sciences: Perils and Prospects, Cambridge, UK Cambridge University Press 2004.

[4] Lipton P. Genetics and genetic determinism: A new threat to free will? In: Rees D, Rose S, Eds. The New Brain Sciences: Perils and
Prospects. Cambridge, UK Cambridge University Press 2004; pp. 88-100.

[5] Bateson P. Genes, responsibility and the law. In: Rees D, Rose S, Eds. The New Brain Sciences: Perils and Prospects. Cambridge, UK Cambridge University Press 2004; pp. 149-63.

[6] Sadley S. Responsibility and the Law. In: Rees D, Rose S, Eds. The New Brain Sciences: Perils and Prospects. Cambridge, UK Cambridge University Press 2004; pp. 123-30.

[7] McCall Smith A. Human action, neuroscience and the law. In: Rees D, Rose S, Eds. The New Brain Sciences: Perils and Prospects. Cambridge, UK Cambridge University Press 2004; pp. 123-30.

[8] Clarke A. On dissecting the genetic basis of behaviour and intelligence. In: Rees D, Rose S, Eds. The New Brain Sciences: Perils and Prospects. Cambridge, UK Cambridge University Press 2004; pp. 181-94

[9] Singer P. Practical Ethics. Cambridge, UK Cambridge University Press 1993; pp. 83-109.

[10] Beauchamp T, Childress FJ. Principles of Biomedical Ethics, Oxford, UK Oxford University Press 1979; pp. 79-81.

[11] Rawls J. A Theory of Justice, Oxford, UK Oxford University Press 1973; 19: 505.

[12] Aristotle. Nicomachean Ethics, I, 2 (1094b).

[13] Aristotle, Politics, I, 2 (1253a19-39)

[14] Guthrie WKC. Socrates, Cambridge, UK Cambridge University Press 1971; pp. 130-42.

[15] MacIntyre A. A short history of ethics, Rutledge, London, UK 1998, chapter 3 . 